\title{
TEACHER'S LEADERSHIP COMPETENCY IN MANAGING ONLINE INSTRUCTION DURING THE PANDEMIC DISRUPTION IN INDONESIA
}

\author{
Sudarmo'), Muslimah'2) \\ ${ }^{1}$ Sekolah Tinggi Ilmu Ekonomi Balikpapan, Indonesia \\ sudarmo@stiebalikpapan.ac.id \\ 2Institut Agama Islam Negeri Palangka Raya, Indonesia \\ Coresponding author: Muslimah.abdulazis@iain-palangkaraya.ac.id
}

\begin{abstract}
Abstrak
Sejak COVID-19 mengguncang dunia, semua aktivitas bisnis mengalami dampak yang sangat besar, termasuk di bidang pendidikan. UNESCO berpesan kepada dunia untuk meredakan dampak pandemi terhadap keberlangsungan pendidikan dunia dengan kebijakan pembelajaran jarak jaub untuk mengatasi gangguan pendidikan. Sejak itu, negara-negara yang terkena pandemi mengalami kesulitan dalam menerapkan pembelajaran jarak jaub tersebut untuk merespon kebijakan. Berkaitan dengan hal tersebut, makalah ini mengidentifikasi kompetensi kepemimpinan instruksional tambahan bagi guru dalam mengelola pembelajaran di masa pandemi. Bukti dari kajian pendidikan menunjukkan bahwa sukses pembelajaran pada masa gangguan sangat erat kaitannya dengan manajemen guru dalam melakukan inovasi pembelajaran virtual berteknologi tinggi. Untuk menemukan jawaban, kami melakukan pembacaan awal dari literatur yang relevan. Selanjutnya, kami menganalisis informasi tersebut secara kualitatif dengan mengeksplorasi manajemen instruksi guru yang dapat diterapkan selama pandemi. Akbir, kami menemukan babwa kompetensi kepemimpinan pengajaran tambahan dapat diadopsi untuk mendukung pembelajaran siswa dalam pendekatan virtual seperti peluang reflektif, meningkatkan kebenaran di antara guru dan siswa, menjaga kebiasaan rasa ingin tabu, membangun komunikasi yang produktif, kebiasaan berinisiatif, dan lebib banyak mendengarkan untuk memahami orang lain. Kompetensi kepemimpinan mengajar tambahan tersebut berguna bagi pihak mana pun yang tertarik untuk mendukung pembelajaran siswa dalam menghadapi gangguan pandemi.

Kata Kunci: Tambahan Kepemimpinan Guru, Kompetensi Kepemimpinan, Mengelola Pembelajaran Jarak Jauh, Gangguan Pandemi.
\end{abstract}

Abstract
Since COVID-19 shocked the world, all business activities experienced an enormous impact, including in the field of education. UNESCO advised the world to ease the pandemic's impact on world education continuity with distance learning policies to overcome this disruption. Since then, pandemic affected countries experienced difficulties implementing that distance learning to respond to the policy. In this regard, this paper was carried out to identify additional instructional leadership competencies for teachers in managing learning in a pandemic. Evidence from the study of education shows that learning in distuption time is closely related to teachers' management in innovating such high technological virtual learning. To find answers, we conducted preliminary readings of the relevant literature. Next, we analyzed that information qualitatively by exploring what teacher instruction management is applicable during the pandemic. Then, we found that additional teaching leadership competencies can be adopted to support students learning in virtual approaches such as reflective opportunities, increasing truth among teachers and students, keeping curiosity habit, building productive communication, initiative habit, and more listening to understand others. Those additional teaching leadership competencies are useful to any party interested in supporting students learning in the pandemic disruption.

Keywords: Additional Teachers Leadership, Leadership Competencies, Managing Long-distance Learning,

Pandemic Disruption; 


\section{INTRODUCTION}

The coronavirus pandemic (COVID-

19) is not only a matter of health threats, but the outbreak also affects all sectors of life, business, and education sustainability. UNESCO has recognized this issue as the pandemic outbreak that has impacted the education sector globally. This international institute estimates that more than two billion students experience disruption of school activities worldwide, and their future education rights are at risk. (Setiawan, 2020; Putra et al., 2020). Likewise, in Indonesia, educational activities also received a considerable impact. Various educational program activities outside the home had to be canceled. After reports of the virus's spread in several neighboring countries, school closings were carried out after reports also increased from yellow zone status to orange and red. As a result of information on the pandemic's spread, all educational activities, both schools, Islamic boarding schools, and universities, must be closed and replaced with distance classes or home learning programs. (Aji, 2020; (Fadlilah, 2020).

To reinforce the government's policy regarding the COVID-19 response utilizing distance learning, the government issued a circular in the form of a school closing policy point but replaced it with online learning classes. The contents of the government's circular are guidelines for organizing learning from home during the emergency period in response to the virus's disruption and spread. To strengthen government policies related to preventing new cases by utilizing distance learning, the government issued a circular form of school closing policy points but replaced it with online learning classes. The government circular contents are a guideline for implementing learning from home during an emergency response to the outbreak's disruption and spread. So it can be ascertained that the disruption response's effect is by closing schools simultaneously and suddenly, then learning from home. With only the teacher council holding on to a study warrant, but without the support of teachers' skills and expertise managing online classes, this is a necessity. Because it can be ascertained that the teachers' ability will significantly determine the success of learning in the emergency period, which is thought only to be a few weeks but has been almost one year running.

König et al., (2020) suggest that teachers' management and leadership adapting to online teaching during the emergency are very beneficial for student learning. (Hutagaluh and Aslan, 2019; (Dewi et al., 2020; Hifza et al., 2020; 
Hutagaluh et al., 2020). Konig's study made perfect sense because, before the pandemic, Indonesia's education world was not so familiar with distance learning and technological innovations. In a crisis, the teachers need adaptation while maximizing online education's management and ability with insights and skills. In this case, the influence of teacher competence and leadership among teachers in increasing the ability to manage technology-based teaching is very appropriate. Their study of adapting to remote education during school closings, the effort to respond to COVID-19 is a solution for the Indonesian learning situation. In other words, mastering the application of teacher technology to innovate in teaching has become an invincible force to be at the forefront of learning management during the crisis of pandemic disruption in Indonesia.

Teacher leadership in responding to learning during the emergency period of COVID-19 should seek self-intellectual growth. Still, it must also help solve the obligation to succeed in student learning during school closures and continue learning virtual classes. Teacher leadership in emergency learning is an essential function of the way they are management which helps increase productivity and learning innovation for students during this period to achieve the goals of emergency education and student learning continuity. However, seeing the facts, teachers' leadership with technological innovations in virtual teaching has not been fully implemented. Because this issue is an important part and a significant component of effective crisis management education that helps maximize student learning efficiency and achieve the national policy goals for school closures during the pandemic (Aji, 2020; König et al., 2020; Munjiat, 2020). It is time for the quality shown by the management and leadership of teachers in teaching during this pandemic disorder such as integrating skills, increasing commitment, sharpening strong communication skills, literacy skills, the courage to initiate, self-wisdom, focus on priorities, generosity, enthusiasm for work, continuing positive attitudes, problem-solving abilities, and high responsibility are consistent with what is expected by the teacher's profession and task(Gunawan et al., 2020).

Regarding the above explanation, we would like to stress here that our aim is that teachers' instructional leadership is very responsible for ensuring student learning at a distance during this crisis. The sense of responsibility of teacher leadership in mastering teacher skills in this technology application can provide further 
benefits to support school learning sustainability while saving students' lives against the threat of a deadly virus. Researchers need to study and convey to many parties the outcome of this project so that there is an increase in good communication about what teachers do in helping students during educational emergencies due to the pandemic and expectation by the teacher's jobs and responsibility. So that with this communication mechanism, there will be input to evaluate teachers' ability in working and learning support resources during the school closing period.

\section{LITERATURE REVIEW}

\section{Teacher's Leadership}

Understanding teacher leadership is often identified with matters of office or power. Whereas leadership in teaching is meant, here is a set of skills usually attached to every teacher when carrying out their duties and obligations. These teaching leadership skills must demonstrate that teachers continue to teach students quality teaching and learning evaluation. This leadership must also have a strong influence on the teacher's appearance while in the classroom to manage learning that is truly strong and sustainable. Leithwood, (2003) states that teacher leadership is something of nature, continues to develop, and impacts schools and students. So, leadership in teachers must contribute to education changes, especially the students' success. Little, (2003) also added that teachers' leadership constructs into three models of policies and activism for reforming leadership and management skills in school education. This construction model emerged in the last two decades on changes in teacher leadership that have emerged as an important element of the reform strategy and world policy rhetoric on the role of teachers in modern times showing how the understanding of teacher leadership changes in line with the demands of educational policy objectives that influence assignments. And the role of teachers as leaders of teaching(Brooks, 2017; Brooks and Mutohar, 2018; Ezzani and Brooks, 2019).

\section{Teacher competence}

Hadar et al., (2020), van der Spoel et al., (2020)said that the understanding of teacher competence must be reviewed in the era of COVID-19. Because teacher education today must be properly competent socio-emotional. They must be ready to help students during a crisis with more competence. Similar to Law No. 14 of 2005 concerning Teachers and Lecturers, article 10 paragraph (1), teacher competence includes pedagogical competence, personality competence, 
social competence and professional competence obtained through professional education. So, educational competence is a mandatory requirement of skills and competency-based teacher assignment, which includes knowledge of the extent, teaching skills, and high scores that a teacher as a participant in student pursuits must have to succeed in education. Teacher competence is the main component that is prepared when completing a teacher education program so that they are ready to answer the challenges of their profession. The characteristics are a teacher with high competence; they can interact well with students. They are educators who can teach high quality to all their students. They are also able to create a learning climate by designing lesson plans.Potential teachers are. They have mastery of various teaching strategies; they are also good at conducting assessments and understand how to find what students need, such as communication and collaboration skills among the council teachers(Leavy, 2016; Musfah and Erviani, 2018).

\section{Managing Online Instruction}

Verawardina et al., (2020) examined online learning during the Covid-19 outbreak. They have successfully analyzed the development and superiority of students' skills through online teaching.
According to their study, online teaching during COVID is very helpful with facilitation that occurs at home. Their understanding of online teaching should be developed to make it easier for students to continue delivering fully online learning. The teacher's function here is instructional handling, which must be designed carefully and carefully planned. Teachers with high leadership often bring in support and design the school media's instructional and service teams. According to many studies, there are five online-based learning methods: hands-on learning, individual student learning, offline teaching, experimentation, and group or collaborative learning. All models must be supported by the tools and understanding of teachers who have high leadership values(Brandmiller et al., 2020).

\section{METHOD}

To answer this research question, we have identified several additional teaching leadership competencies for teachers to learn to continue achieving maximum learning outcomes in pandemic disruption from various literature. In particular, we have preliminary readings with evidence from previous educational studies. After gathering the information, we then analyzed it with an in-depth interpretation of the phenomenological approaches to ensure that our findings are valid and 
reliable (McMillan and Schumacher, 2010; Selvi, 2008) Therefore, we have structured the result by describing the answers to this study's findings, describing the research protocol, explaining in good measurements we made, and no calculations were carried out as this study was not quantitative research, and no any statistical tests were carried out to analyze the data.

\section{FINDING AND DISCUSSION}

This section of the findings aims to report some of the teaching leadership competencies that teachers can have in managing online teaching in crisis times due to pandemic disruption in Indonesia. In general, in this section, virtual-based learning can be explained when there are COVID-19 disruption and solutions that can be adopted, and some have been carried out by teachers both online and offline classes. We acknowledge that the threat of an outbreak has forced teachers to continue implementing virtual learning systems. On the other hand, this epidemic cannot fully impact distress but has become a way without us thinking that the emergence of a pandemic has also forced teachers to innovate and revolutionize educational journeys, especially in countries that have not been accustomed technology-based learning.
This approach is taken by the teachers based on consideration and fear of a large number of news about the increasing number of new victims both from the government and daily conversations in the community so that the community is increasingly reluctant to send their children back to school. Even so, although distance learning has been going on for almost a year with the implementation of online classroom policies, many teachers and students still do not understand what this online system learning method is assisted by several computer applications, such as Google Classroom, Google Meet, Edmundo, and other applications

While offline or offline learning means learning using media, such as television and radio. Pay attention that in every crisis, there are always leaders who appear without anyone giving orders. Likewise, when the COVID-19 pandemic hit education, figures emerged who were willing to act as leaders, and their presence might have been as heroes to save education in society. Even though it appeared like an emergency, his enthusiasm and dedication were extraordinary in keeping knowledge in a time of pandemic crisis, which was full of uncertainty. However, there is nothing wrong with the teaching leaders being supported by various skills and 
competencies in line with the improving situation. Their roles can indeed continue the sustainability of student education amid pandemic disturbances. Therefore, in the followings are some quality and competencies of leadership teachers:

\section{Reflective opportunity}

Competence to recognize the teacher's role as a dedicated educator under challenging times due to pandemic disturbances will help teachers' outstanding support. Self-reflection means that teachers can know their strengths and ability to support student learning so that they can share these competencies with other teachers in right time, especially their students who are waiting the teacher roles in managing students learning from home. Inatsthe sense, the ability to tell stories about how to reflect force on fellow teachers will help other teachers. In other words, when teachers reflect on this competency, other teachers will exemplify this so that they will be able to create a distance learning environment during the COVID-19 crisis to be more meaningful and authentic climate of learning. The teachers' self-reflection competence is a good moment to share the teachers' understanding and insights to think about their solutions, values, and strengths as teachers as educational leaders in difficult times due to this uncertain crisis. Teachers can do this reflection; there are many activities to help teachers reflect on various resources obtained through many learning materials under the scholarly sources. So that teachers can build awareness and selfability to develop their leadership potential towards patterns of improving student learning conditions online when COVID19 hits education. It is a similar activity that is often used in business service organizations; for example, SWOT analysis to reflect on the strengths, weaknesses, opportunities, and threats of the school or area where the teachers are assigned can help guide decisions and the next steps for student learning, even though it is a longdistance way with the help of combined blended learning.

\section{Increase Trust}

To succeed in teaching innovations in the future, teachers need support, understanding, and trust from friends and audiences to help the teacher team be ready to provide feedback and take risks. Without truth from other teachers, failure in teaching will very easily happen. Truth from teacher colleagues is very necessary when teachers are working during COVID-19. During this difficult period, all teachers and students are no longer able to see which learning solutions are solutions. So at's when the teacher is the truth to share expertise and commitment to a 
solution so that teachers and other school communities get peace, not panic. Is how competent teachers demonstrate the abilities that build colleague trust. In this way, the truth teacher allows other teachers to learn from each other but is also oriented towards remote learning solutions in difficult times of pandemic disruption.

A great solution is for the teacher to focus on building a culture of thought, developing a mind. Just because teachers are in a distance learning environment does not mean that teachers and students can forget about intellectual culture and character. Make sure as a teacher leader who can take the time to think strategically about culture and character building for identity and high morality. If the teacher needs some enrichment of ideas, study these strategies to build and sustain a culture in an isolated and distance learning environment.

\section{Curiosity habit}

Teachers' curious nature allows them to continue to find solutions to problems in their work, responsive to student needs as natural as learning from home is very limited. The obstacles affected by the pandemic have indeed blocked all access to learning. So teachers who have high-quality leadership know this is difficult but not insane, especially during this challenging time; students have to star and learn only from home, but as a highly dedicated teacher, always feel it is important to make sure they take the time to continue to have a sense of curiosity. Continue. The trick may be to employ one of the best ways to motivate students and parents at home by giving learning ownership. Curious teachers will do this with the help of technological tools like Google and other applications. Such teachers know the percentage between learning time for selfdevelopment and serving students during online learning. Teacher solutions can be online studies, case studies, or practical problem-solving. Each teacher gets their plan of action, with check-in meetings like students would during super hours in class. The point is that teachers with high leadership potential always foster curiosity through the choice of teachers with the help of technology.

\section{Productive communication}

One of the attributes of academic competence is communication skills. Because these skills are the key to the team's success in general, including communication in educational activities. Likewise, communication flow during education is under the influence of COVID-19; here, communication for teachers is very important in carrying out remote teaching tasks. It must be admitted that communication so far has been greatly 
influenced by time and space boundaries. However, if contact can be arranged, it will certainly make teachers and other teams aligned and work to achieve the objectives of implementing learning during pandemic disruption.

A great solution during the online learning period is that teachers should continue improving their online communication skills with the student community.Because online communication's typical success is closely related to digital technical management skills, sometimes the students themselves are updated with all kinds of tools. Students are called the millennial or digital native generation, while old age teachers are the digital immigrant generation. Having open working hours allows teachers to take advantage of online conversations with the most viral topics, innovative ideas that students like, or discussions about things of interest to remote generations in a good way to get feedback from students and teachers. The solution is to capture information and share it in the form of learning to students. Sharing teacher success stories with students are very important so that the online learning climate will continue to grow and be attractive. One of the right ways to succeed in virtual learning victories is teachers' and school parties' success is to have a free communication flow in a fast network that allows the learning community to share learning and work achievements.

\section{Listento understand}

If teachers want to work together with students, they have to learn from each other. Listening to understand helps increase collaboration and better engagement by aligning the results and anticipating miscommunication among the learning community. One of the best ways to show that teachers are listening to students is to practice the good rule of hearing, which means that teachers give full attention percent of their attention and focus on their students' students. To make this happens, it takes an extra step for the teachers to close their communication or turn their cell phones down while going online contact. It is even harder to do when they are in a virtual meeting. However, one-way teachers can do this is by simply opening the meeting link, such as Google classroom, Zoom, and other teleconference platforms. Teachers have to show their ways if they can play in the video to see if they are good listeners, not just more on typing email students in the whole semester.

\section{Initiative habit}

Teachers' professional life in the pandemic era is very different from the 
normal day era. Teachers are very easily tired in every decision-making when there is a problem, and it is often easy to feel helpless anymore. Teachers need to have a thorough process and training to help handle decision making whenever needed. The ability to take the initiative in decisions greatly helps to be a more empowered decision-maker. This initiativefilled action is a hallmark of leadership traits in the world of teacher training. It is more so during the pandemic disorder where all the problems were in a completely uncertain state. Suppose this is indeed the challenge, then by using an important outpouring of opinion. It is practiced while asking oneself what will cause the problem to be handled if learning to shift tasks. Maybe ask questions and dare to help solve any challenges and difficulties in completing teaching assignments in the COVID-19 season.

Use a reverse brainstorming protocol to develop decisions that will lead the team to the desired outcome. Learn more about asking for a reverse opinion here. Make room for failure. Teachers should frequently talk about helping students during home learning and growing with their families' help. What potential can students use to reach their learning assignments to achieve what is expected by the school? To provide space for teachers to lead to innovation must be a shared priority to be creative and initiative. Teacher habits, such as helping students with online learning solutions, should be proactive with the teacher council to maximize the decision-making process and minimize risks. Teachers who have potential leaders must rely on each other and explore and learn to find the resilience to manage the uncertainty of knowledge in the pandemic era.

This section of the discussion will discuss additional instructional leadership competency analysis for teachers in managing learning in a pandemic for Indonesia's education. Reflective opportunities for teachers have been very useful in helping students learn so far. This useful of reflexive competence is proved by the findings of Ferdig et al., (2020) concerning the study of teaching during the pandemic in the United States, which places the ease of technology to support teacher education. It is part of teachers who have successfully anticipated learning obstacles during the US education hit by COVID-19. It proves how collaborative leadership is for the continuity of student education with computational literacy. The same study came from Assunção Flores and Gago, (2020) where the continuity of education in many countries affected by COVID-19 has been helped by teachers' 
ability with the reflective story method during the pandemic in Portugal. The collaboration of teachers as a national effort and response takes a pedagogical approach while the pandemic crisis disrupts education.

Apart from that, teachers' effort to increase the trust with the quality and capacity of intellectual self-abilities is also a key in solving daily problems at work so that fellow teacher councils and students will increase the degree of truth to their teachers. Studies Toquero, (2020), which describes several challenges and opportunities for increasing the resilience of higher education during the pandemic among Philippine universities, has proven that university managers' truth is critical to continuing education there. Truth and the quality of a lecturer, for example, greatly determine the level of success in work. On the other hand, the study of Ferdig et al., (2020) also reveals that teaching during the COVID-19 period is highly dependent on technology and the skills of teachers as a truthfulness during the pandemic. Teachers will easily show a high leadership level if they are individuals with high truth and integrity in their daily work during difficult times.

The truth, the teachers, must be able to make students maintain a habit of curiosity. Because this habit of curiosity will make students want to know something without being pushed by the school. This habit is very appropriate for students to have when students have to study at home with minimal support from the teacher or student guardian. Reimers and Schleicher, (2020) has contributed to the success of teaching and learning during the COVID-19 pandemic by continuing to motivate students and teachers with the habit of increasing their curiosity about all fields of knowledge and skills. Because in life today, there is technology support so that teachers can continue to innovate technology so that talent and curiosity can continue.

The best teacher good leadership quality is efforts to build productive communication in the workplace are necessary. Especially for teachers when carrying out their duties to deliver good teaching in all communication. Because communication skills are the main competencies that students must-have, the teacher must first start these skills. Dirani et al., (2020), examine leadership competencies and the important role of human resource development in crisis times, starting from communication competencies in response to all challenges during a pandemic. Undoubtedly, this is the main aspect of human resource development efforts in today's digital era. 
Thus Barrett, (2006) long ago advised that strong communication skills are a must for today's leaders. So the teacher for the present century is the number one leader who is at the forefront of guarding the sustainability of education, especially in difficult times of the pandemic.

The habits of successful teachers usually come from a high level of initiative and activity the teachers have. Moreover, individuals who never stop with initiative and creativity in overcoming student learning difficulties during crisis times are needed. Suppose the teacher does something through the orders of others. In that case, this is the teacher who will experience a period of setback and the impact on the generation of students who will continue to be left behind, especially when academic life is affected by many problems and disturbances. Azorín, (2020) researches beyond the supernova COVID19 , is there any other education coming? Of course, if humans want to take the initiative to make this pandemic the main capital journal towards new skills in the education and business community. Likewise, Mitani et al., (2020) examine that learning will not stop if teachers can initiate learning during the disruption of China's COVID-19 outbreak. They said implementing creative teacher-assisted practices, and open educational resources would continue learning activities in a smart learning environment.

Finally, this discussion would talk about the habit of being a loyal listener is a good skill. Because if we listen to understand, it will solve the problem. Likewise, teachers' traditions in solving problems have to hear a lot from students and other teacher friends. Raaper and Brown, (2020) examined the effects of the Covid-19 pandemic and campus holidays but still opened long-distance classes. The implication they get is that the most effective method is to listen more to the world of lecture practice in providing full support to students. So the teachers must be able to speak well so that the academic community can listen well to their campuses' development during the pandemic. Likewise, Hodges et al., (2020) examines the difference between emergency distance teaching and online learning is the listening factor and assesses each learning activity.

From our six findings regarding the study of teacher management in developing teaching leadership skills during COVID-19, of course, there are many weaknesses and limitations of our roaming capacity. However, we have to acknowledge that this is only an addition to teachers' skills and competencies if they want to back up student remote teaching 
during a pandemic. However, we do believe that those findings have answered the research question.

\section{CONCLUSION}

The main objective of this study is to find answers to these defining questions. The problem is that we analyzed the additional leadership competencies of teachers in continuing teaching during the COVID-19 period by utilizing distance education whose orientation is to sustain education and achieve high learning outcomes. Considering the variety of evidence from previous studies, particularly studies on learning disrupted by epidemics, we can formulate some additional findings to complement online teaching insights. Therefore, we may briefly mention that additional teacher's leadership competencies has been used to support learning from home in virtual approaches such as reflective opportunities, increasing truth among teachers and students, keeping curiosity habit, building productive communication, initiative habit, and more listening to understand others. We have compiled all the teacher leadership skills in a very simple way, making it possible for them to be understood even by non-educators.

Among them, teachers must continue to be willing to reflect on themselves to improve their teaching quality. Other findings include increasing the truth among teachers and students to continue to believe in teachers even though they are now living and learning in difficult times. Likewise, the teacher must maintain a habit of inquisitive learning so that new knowledge and understanding continues. On the other hand, teachers must also build productive communication between teachers and students, even though they are far away. We also suggest that everyone has the habit of taking the initiative and being critical whenever something new comes up without waiting for orders from superiors or others. The last one is the teacher's listening habit of understanding other people, especially the listeners or students in the class.

\section{REFERENCES}

Aji, R.H.S., 2020. Dampak Covid-19 pada Pendidikan di Indonesia: Sekolah, Keterampilan, dan Proses Pembelajaran. Salam J. Sos. Dan Budaya Syar-I7 5, 395-402.

Assunção Flores, M., Gago, M., 2020. Teacher education in times of COVID-19 pandemic in Portugal: national, institutional and pedagogical responses. J. Educ. Teach. 1-10.

Azorín, C., 2020. Beyond COVID-19 supernova. Is another education coming? J. Prof. Cap. Community.

Barrett, D.J., 2006. Strong communication skills a must for today's leaders. Handb. Bus. Strategy.

Brandmiller, C., Dumont, H., Becker, M., 2020. Teacher Perceptions of Learning Motivation and Classroom Behavior: The Role of 
Student Characteristics. Contemp. Educ. $\quad 101893$. https://doi.org/10.1016/j.cedpsyc h. 2020.101893

Brooks, M.C., 2017. Southern Filipino school leaders and religious diversity: a typology. Int. J. Educ. Manag. 31, 646-660. https://doi.org/10.1108/IJEM-082016-0164

Brooks, M.C., Mutohar, A., 2018. Islamic school leadership: a conceptual framework. J. Educ. Adm. Hist. 50, 54-68.

https://doi.org/10.1080/00220620 .2018 .1426558

Dewi, N.C., Aslan, Suhardi, M., 2020. GAYA KEPEMIMPINAN KEPALA SEKOLAH TAMAN KANAK-KANAK. JMSP J. Manaj. Dan Supervisi Pendidik. 4, 159-164.

Dirani, K.M., Abadi, M., Alizadeh, A., Barhate, B., Garza, R.C., Gunasekara, N., Ibrahim, G., Majzun, Z., 2020. Leadership competencies and the essential role of human resource development in times of crisis: a response to Covid-19 pandemic. Hum. Resour. Dev. Int. 23, 380-394.

Ezzani, M., Brooks, M., 2019. Culturally Relevant Leadership: Advancing Critical Consciousness in American Muslim Students. Educ. Adm. Q. 55 , 781-811.

https://doi.org/10.1177/0013161 X18821358

Fadlilah, A.N., 2020. Strategi Menghidupkan Motivasi Belajar Anak Usia Dini Selama Pandemi COVID-19 melalui Publikasi. J.
Obsesi J. Pendidik. Anak Usia Dini 5, 373-384.

Ferdig, R.E., Baumgartner, E., Hartshorne, R., Kaplan-Rakowski, R., Mouza, C., 2020. Teaching, Technology, and Teacher Education during the COVID-19 Pandemic: Stories from the Field. Association for the Advancement of Computing in Education (AACE).

Gunawan, G., Suranti, N.M.Y., Fathoroni, F., 2020. Variations of Models and Learning Platforms for Prospective Teachers During the COVID-19 Pandemic Period. Indones. J. Teach. Educ. 1, 61-70.

Hadar, L.L., Ergas, O., Alpert, B., Ariav, T., 2020. Rethinking teacher education in a VUCA world: student teachers' social-emotional competencies during the Covid-19 crisis. Eur. J. Teach. Educ. 1-14.

Hifza, Suhardi, M., Aslan, Ekasari, S., 2020. KEPEMIMPINAN PENDIDIKAN ISLAM DALAM PERSPEKTIF

INTERDISIPLINER. Nidhomul Haq J. Manaj. Pendidik. Islam 5, 46-61.

https://doi.org/10.31538/ndh.v5i 1.518

Hodges, C., Moore, S., Lockee, B., Trust, T., Bond, A., 2020. The difference between emergency remote teaching and online learning. Educ. Rev. 27.

Hutagaluh, O., Aslan, 2019. Pemimpin dan Pengaruh Geo Politik Terhadap Lahirnya Sumber Daya Manusia Yang Berkarakter. J. Studi Islam Lintas Negara 1, 23-29.

Hutagaluh, O., Aslan, Putra, P., Syakhrani, A.W., $\quad$ Mulyono, S., 2020. 
SITUATIONAL LEADERSHIP ON ISLAMIC EDUCATION. IJGIE Int. J. Grad. Islam. Educ. 1, $1-7$.

König, J., Jäger-Biela, D.J., Glutsch, N., 2020. Adapting to online teaching during COVID-19 school closure: teacher education and teacher competence effects among early career teachers in Germany. Eur. J. Teach. Educ. 1-15.

Leavy, B., 2016. Effective leadership today - character not just competence. Strategy Leadersh. 44, 20-29. https://doi.org/10.1108/SL-112015-0081

Leithwood, K., 2003. Teacher leadership: Its nature, development, and impact on schools and students. Leadersh. Educ. 103-117.

Little, J.W., 2003. Constructions of teacher leadership in three periods of policy and reform activism. Sch. Leadersh. Manag. 23, 401-419.

McMillan, J.H., Schumacher, S., 2010. Research in Education: EvidenceBased Inquiry, MyEducationLab Series. Pearson.

Mitani, A., Huang, A., Venugopalan, S., Corrado, G.S., Peng, L., Webster, D.R., Hammel, N., Liu, Y., Varadarajan, A.V., 2020. Detection of anaemia from retinal fundus images via deep learning. Nat. Biomed. Eng. 4, 18-27.

Munjiat, S.M., 2020. Implementation of Islamic Religious Education Learning in Higher Education on The Pandemic Period. Nazhruna J. Pendidik. Islam 3, 285-295. https://doi.org/10.31538/nzh.v3i2 .757
Musfah, J., Erviani, D., 2018. School of Master Teacher (smt) Training: Developing Teachers' Pedagogic Competence. TARBIYA J. Educ. Muslim Soc. 5, 126-134. https://doi.org/10.15408/tjems.v5 i2.10622

Putra, P., Liriwati, F.Y., Tahrim, T., Syafrudin, S., Aslan, A., 2020. The Students Learning from Home Experiences during Covid-19 School Closures Policy In Indonesia. J. Iqra Kaji. Ilmu Pendidik. 5, 30-42. https://doi.org/10.25217/ji.v5i2.1 019

Raaper, R., Brown, C., 2020. The Covid-19 pandemic and the dissolution of the university campus: Implications for student support practice. J. Prof. Cap. Community.

Reimers, F.M., Schleicher, A., 2020. A framework to guide an education response to the COVID-19 Pandemic of 2020. OECD Retrieved April 14, 2020.

Setiawan, A.R., 2020. Scientific Literacy Worksheets for Distance Learning in the Topic of Coronavirus 2019 (COVID-19).

Toquero, C.M., 2020. Challenges and Opportunities for Higher Education amid the COVID-19 Pandemic: The Philippine Context. Pedagog. Res. 5. https://doi.org/10.29333/pr/7947 van der Spoel, I., Noroozi, O., Schuurink, E., van Ginkel, S., 2020. Teachers' online teaching expectations and experiences during the Covid19pandemic in the Netherlands. Eur. J. Teach. Educ. 1-16. 
Nidhomul Haq, Vol 5 No 3. Tahun 2020

Verawardina, U., Asnur, L., Lubis, A.L., Hendriyani, Y., Ramadhani, D., Dewi, I.P., Darni, R., Betri, T.J., Susanti, W., Sriwahyuni, T., 2020.

Reviewing Online Learning Facing the Covid-19 Outbreak. Talent Dev. Excell. 12. 